\title{
KIMBERLITES OF THE NAKYN FIELD, SIBERIA, AND THE SNAP LAKE/KING LAKE DYKE SYSTEM, SLAVE CRATON, CANADA: A NEW VARIETY OF KIMBERLITE WITH A PROPOSED ULTRADEEP ORIGIN
}

\author{
Nick Pokhilenko ${ }^{1,2,3}$, Alexei Agashev**1,3, John McDonald ${ }^{2}$, Nick Sobolev ${ }^{1}$, Sergei Mityukhin ${ }^{3}$, \\ E. Takazawa ${ }^{4}$, Mikhail Vavilov ${ }^{1}$, and Yuri Yanygin ${ }^{3}$ \\ ${ }^{I}$ Institute of Mineralogy and Petrography, Novosibirsk, Russia. ${ }^{2}$ Diamondex Resources Ltd., Vancouver, Canada. \\ ${ }_{3}^{3}$ ALROSA Co. Ltd., Mirny, Russia ${ }^{4}$ Niigata University, Niigata, Japan.
}

\section{INTRODUCTION}

Diamondiferous kimberlites of Siberia's Nakyn Field (NF), specifically the Nyurbinskaya and Botuobinskaya pipes, and those of the Snap Lake/King Lake (SL/KL) kimberlite dyke system, Slave Craton, Canada, are important geological discoveries of the late $20^{\text {th }}$ century. The rocks from both localities have specific mineralogical, geochemical and petrological features separating them from known kimberlites, as well as features linking them to those of Groups I \& II kimberlites. Data from ongoing studies of the NF and $\mathrm{SL} / \mathrm{KL}$ kimberlites indicates a proposed ultradeep source of these kimberlites compared to other known kimberlites. These rocks provide a unique opportunity to obtain new information on the mantle structure, composition and magma generation process.

\section{METHODS AND RESULTS}

Major element compositions of the diamond inclusions and diamond indicator minerals have been analyzed using CAMEBAX-Micro, Cameca, electron microprobe at the Analytical Center of the UIGGM SB RAS, Novosibirsk, Russia. Sr and Nd isotope compositions of the kimberlites were measured at the Division of Earth and Planetary Science, Graduate School of Science, Hokkaido University, Japan using a Finnigan MAT 262 mass spectrometer equipped with seven collectors and operating in static mode (Orihashi et al. 1998). Trace elements were determined by ICPMS at Niigata University, Japan, using state-of-the-art procedures as described in Eggins et al. (1997). A multi-elemental internal standard was added to each sample, which allowed the monitoring and correction of the complex mass-dependent variation in instrument sensitivity.

The results of ongoing mineralogical and geochemical studies of NF and SL/KL rocks are briefly summarized here, and their important characteristic features provided. Features common to the Nakyn and SL/KL kimberlites include: 1) their micaceous character and relatively low $\mathrm{K}_{2} \mathrm{O} / \mathrm{TiO}_{2}$ ratios (Fig.1); 2) a wide range of $\mathrm{CaO}$ contents (e.g. 0.6-26.5 wt.\% for $\mathrm{SL} / \mathrm{KL}$ kimberlites) related to wide variations of carbonatite component; 3) very trace amounts of magnesian ilmenite and perovskite; 4) low total content of diamond indicator minerals (Cr-pyropes and chromites) (e.g. $<0.5 \mathrm{~kg} /$ tonne); 5) a very wide range of $\mathrm{Cr}_{2} \mathrm{O}_{3}$ content in pyropes (up to $17 \mathrm{wt} . \%$ for SL/KL and up to 15 wt.\% for Nakyn kimberlites) Pokhilenko et al . (2000); 6) an abnormally high proportion of high-Cr (> 62 wt. $\left.\% \mathrm{Cr}_{2} \mathrm{O}_{3}\right)$ - low Ti $\left(<0.7\right.$ wt. $\% \mathrm{TiO}_{2}$ ) chromites (up to 27 and $42 \%$ respectively); 7) a high diamond grade with a high proportion of octahedral and coated diamonds; 8) undifferentiated composition of $\mathrm{Nd}$ isotopes that have a nearly chondritic value at the time of kimberlite emplacement (Fig. 2).

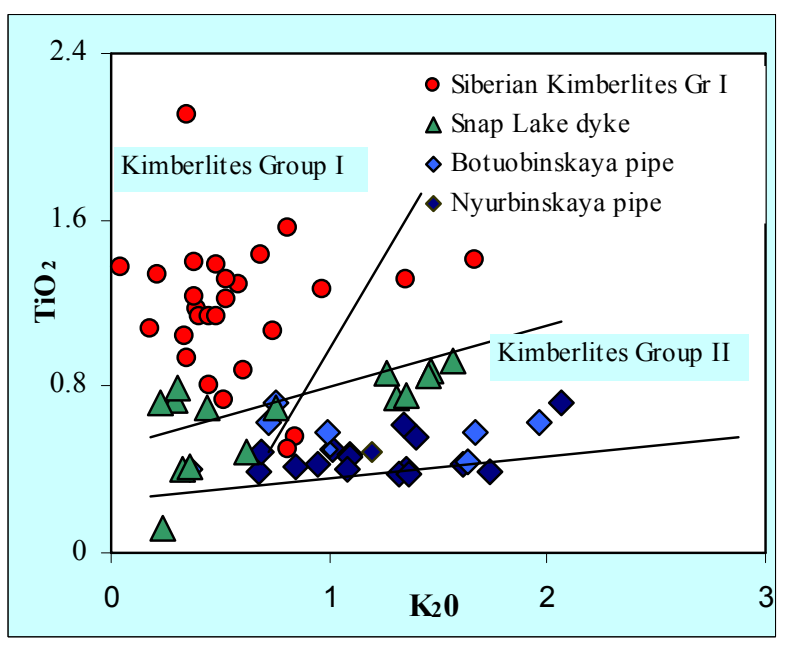

Figure 1. $\mathrm{TiO}_{2}-\mathrm{K}_{2} \mathrm{O}$ relationship in the $\mathrm{NF}$ and $\mathrm{SL} / \mathrm{KL}$ kimberlites in comparison with the Siberian Group I and South African Groups I\&II kimberlites. The fields of Groups I\&II kimberlites are after Smith et al. (1985).

Geochemical features similar to those of Group I kimberlites for NF kimberlites include: 1) low $\mathrm{La} / \mathrm{Nb}$ ratio (0.58), and 2) $\mathrm{Nd}$ isotope compositions (Fig. 2). For SL/KL kimberlites they include: 1) trace element 
distribution pattern; 2) $\mathrm{Sr}$ and $\mathrm{Nd}$ isotope compositions; and 3) $\mathrm{Nb} / \mathrm{Zr}(>1)$ and $\mathrm{La} / \mathrm{Nb}$ ratios $(<1)$.

Geochemical features similar to those of Group II kimberlites for NF kimberlites are: 1) the pattern of trace element distribution (Fig.3), and 2) $\mathrm{Nb} / \mathrm{Zr}(\sim 0.4)$ and $\mathrm{TiO}_{2} / \mathrm{K}_{2} \mathrm{O}(\sim 0.43)$ ratios (Fig.1). For the SL/KL kimberlites they include: 1$) \mathrm{TiO}_{2} / \mathrm{K}_{2} \mathrm{O}$ ratios $(0.37-2.6)$ (Fig. 1), and 2) Ba, Th and LREE abundances (Fig. 3).

Geochemical features intermediate between those of Group I and II kimberlites for NF kimberlites include $\mathrm{Ba} / \mathrm{Nb}(0.95)$ and $\mathrm{Ni} / \mathrm{MgO}(45.2)$ ratios. For the $\mathrm{SL} / \mathrm{KL}$ kimberlites they include: 1) distribution of the most incompatible elements ( $\mathrm{Pb}, \mathrm{Rb}, \mathrm{La}, \mathrm{Ce})$ (Fig. 3), and 2) some $\mathrm{TiO}_{2} / \mathrm{K}_{2} \mathrm{O}$ ratios.

The distinctive feature separating the NF and SL/KL kimberlites is the incompatible element concentration. $\mathrm{NF}$ rocks contain less of them than any known kimberlites (Agashev et al., 2001), whereas the SL/KL dyke system rocks are enriched in these elements (Fig. 3 ), more than kimberlites of Group I and comparable to kimberlites of Group II.

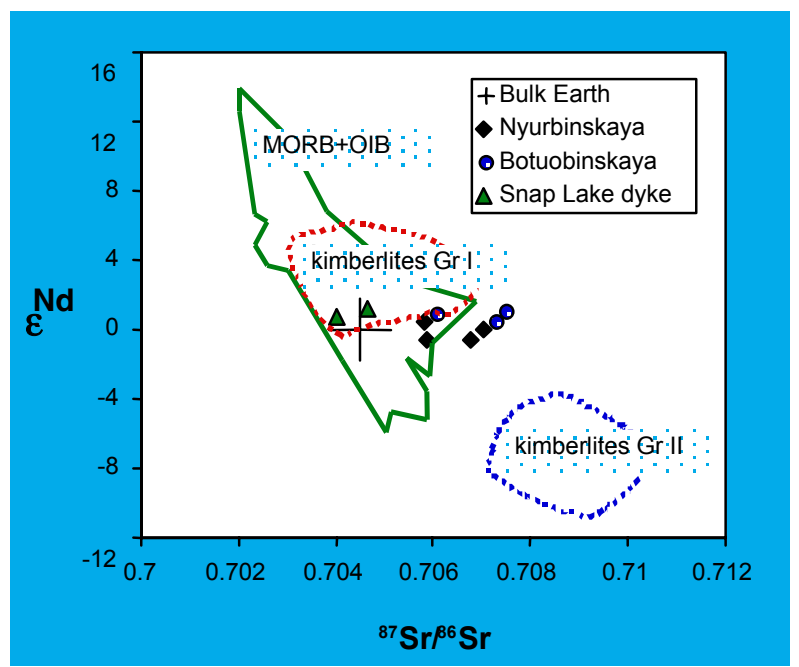

Figure 2. $\mathrm{Sr}$ and $\mathrm{Nd}$ isotope composition of $\mathrm{NF}$ (Nyurbinskaya and Botuobinskaya pipes) and SL kimberlites calculated back to the time of emplacement- $t$. The fields of MORB and OIB (Hofmann, 1997) and groups I\&II kimberlites (Smith et al, 1983) are shown. $t=364$ Ma for $\mathrm{NF}$ and $535 \mathrm{Ma}$ for SL/KL kimberlites.

\section{DIscussion}

The existence of very thick lithosphere beneath the $\mathrm{SL} / \mathrm{KL}$ area at emplacement age, is supported by the presence of majorite-bearing (up to $17 \mathrm{~mol} \%$ ) high$\mathrm{Mg}$, high-Cr subcalcic pyropes as $\mathrm{SL} / \mathrm{KL}$ diamond inclusions (Pokhilenko et al., 2001). These majoritebearing pyropes are most probably related to depleted, ultramafic rocks (harzburgites) of the lithospheric mantle (Pokhilenko et al., this volume). Although, the data on the inclusions in diamonds is not yet available for the NF kimberlites, the similarity of the composition of the diamond indicator minerals between the NF and $\mathrm{SL} / \mathrm{KL}$ rocks suggests similarity in depth and composition of the lithospheric mantle sampled by these kimberlites.

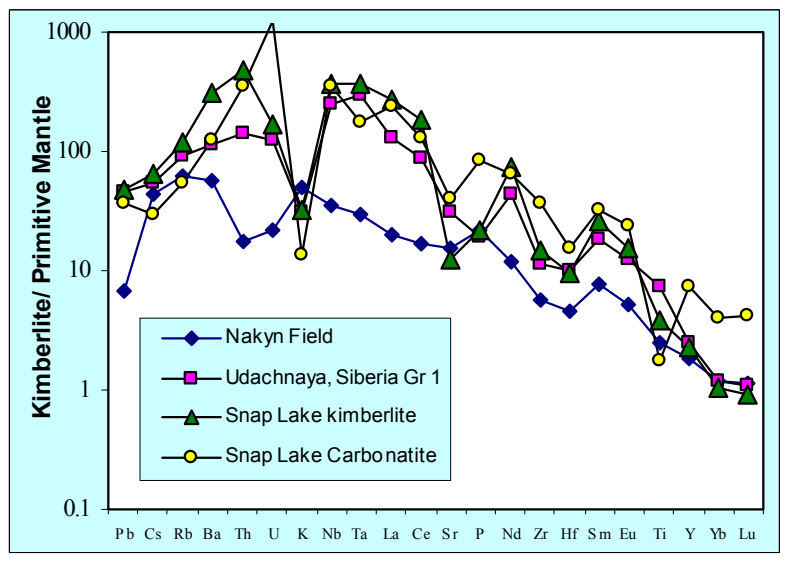

Figure 3. Primitive mantle normalized trace elements patterns of NF kimberlites and SL/KL dyke kimberlites and carbonatites. Composition of Udachnaya kimberlites is from Agashev (2002a). Primitive mantle composition used for normalization is from McDonough and Sun (1995).

The geochemical signatures of rocks from both localities provides additional evidence for deep source regions. In the NF kimberlites, this deep source can be traced from the inter-element ratios. The calculation of partial melting in terms of $\mathrm{Sm} / \mathrm{Nd}$ and $\mathrm{Lu} / \mathrm{Hf}$ ratios indicates NF kimberlites can be generated by $0.5 \%$ partial melting of a source with primitive mantle composition (Agashev, 2002a), whereas all other kimberlites require significantly incompatible-element enriched source compositions. Another important feature of NF kimberlites is their superchondritic $\mathrm{Nb} / \mathrm{Ta}$ ratios (21-24). These ratios can be inherited from the "missing reservoir" of Barth et al. (2000), which is located at the core-mantle boundary (Rudnick et al., 2000) and carried upwards to the lithospheric roots by mantle plume (Agashev et al., 2002b).

The chemical composition of SL/KL rocks ranges from magnesiocarbonatites (with $\mathrm{SiO}_{2}$ contents of $\sim 3 \mathrm{wt} \%$ ), to carbonatitic kimberlites, through to typical kimberlites. The composition of carbonatites and kimberlites is in excellent agreement with that of melts obtained in carbonated lherzolite melting experiments that were done at 6 Gpa (Dalton and Presnall, 1998). Distribution characteristics of HREE, Y, Zr and Rb, K, $\mathrm{Ba}$ between the SL/KL carbonatites and kimberlites suggests that they were produced by primary partial melting of slightly carbonated depleted lherzolites. This melting process occurred at depths exceeding $300 \mathrm{~km}$, 
as indicated by the composition of majorite garnet inclusions in SL/KL diamonds. At a partial melting level of about $0.3-0.6 \%$ the liquid was mainly magnesiocarbonatitic, and at levels of $1 \%$ and more the liquid was kimberlitic in composition. In the SL/KL rocks the superchondritic $\mathrm{Nb} / \mathrm{Ta}$ ratios can be explained by fractionation during partial melting in the mantle.

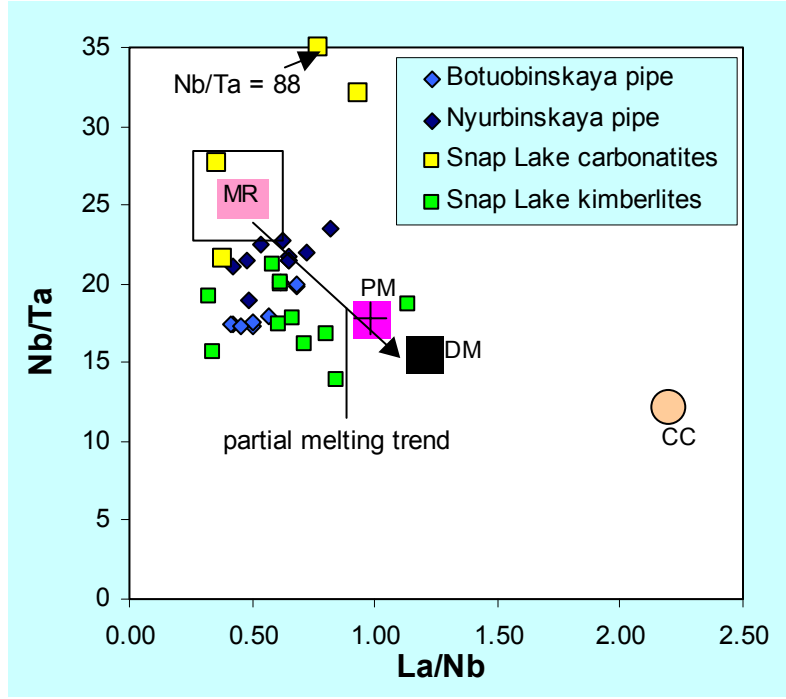

Figure 4. $\mathrm{La} / \mathrm{Nb}$ vs. $\mathrm{Nb} / \mathrm{Ta}$ ratio diagram for Nakyn field kimberlites and for Snap Lake dyke (Canada) rocks. PM (Primitive mantle), DM (Depleted mantle) and CC (Continental crust) compositions are shown for comparison. MR is "Missing Reservoir"after Barth et al. (2000). Partial melting trend is shown by line with the arrow.

Both the $\mathrm{Nb} / \mathrm{Ta}$ ratios and the $\mathrm{Zr} / \mathrm{Hf}$ ratios are significantly superchondritic in carbonatites and display a negative correlation with $\mathrm{SiO}_{2}$ contents. The $\mathrm{Nb} / \mathrm{Ta}$ ratio in carbonatites ranges from slightly superchondritic $\left(\mathrm{Nb} / \mathrm{Ta}=22\right.$ and $\left.\mathrm{SiO}_{2}=17 \mathrm{wt} \%\right)$ to superchondritic $\left(\mathrm{Nb} / \mathrm{Ta}=81\right.$ and $\left.\mathrm{SiO}_{2}=3.7 \quad \mathrm{wt} \%\right)$, whereas $\mathrm{Nb} / \mathrm{Ta}$ ratio in kimberlites scatters around the chondritic value of 18 .

\section{CONCLUSIONS}

The geochemical and mineralogical features of both the Nakyn kimberlites and the SL/KL kimberlitecarbonatite association require a specific source located at depths of $\sim 300 \mathrm{~km}$ within the lithospheric mantle, much deeper than source depths postulated for known Siberian and South African kimberlites. These results indicate that the Nakyn and SL/KL kimberlite suites were sourced in, and sampled en-route, similar deepseated levels of lithospheric mantle as shown by their diamond indicator minerals. However, geochemical data indicate that the source of the SL/KL kimberlites was pre-enriched in incompatible elements directly before the kimberlite formation. For NF rocks, this preenrichment stage was missed.

\section{REFERENCES}

Agashev A.M., Watanabe T., Budaev D.A., Pokhilenko N.P., Fomin A.S., Maehara K., and Maeda J., 2001. Geochemistry of Nakyn field kimberlites Siberia: evidence for a unique source composition. Geology. 3, 267-270.

Agashev A.M., 2002a. Rb-Sr and Sm-Nd isotope systematic and trace elements geochemistry of Siberian kimberlites. Ph.D. Thesis, Hokkaido Univ. Sapporo, Japan.

Agashev A.M., Pokhilenko N.P., Takazawa E., Watanabe T., McDonald J.A., Sobolev N.V., Vavilov M.A., and Fomin A.S., 2002b. Do superchondritic $\mathrm{Nb} / \mathrm{Ta}$ ratios in kimberlites tell the lower mantle plume signature? Extended Abstract on the $2^{\text {nd }}$ International Superplume Workshop, Tokyo, Japan.

Barth M.G., McDonough W.F and Rudnick R.L., 2000. Tracing the budget of $\mathrm{Nb}$ and $\mathrm{Ta}$ in the continental crust. Chem.Geology. 165, 197-213.

Dalton J.A and Presnall D.C., 1998. The continuum of primary Carbonatitic-kimberlitic melt compositions in equilibrium with lherzolite: Data from the system $\mathrm{CaO}-\mathrm{MgO}-\mathrm{Al} 2 \mathrm{O} 3-\mathrm{SiO} 2-\mathrm{CO} 2$ at 6GPa. J. of Petrology. 39, 1953-1964.

Hofmann, A.W., 1997, Mantle geochemistry: the message from oceanic volcanism: Nature, v. 385, p. 219-229.

Eggins, S.M., Woodhead, J.D., Kinsley, L.P.J., Mortimer, G.E., Sylvester, P., McCulloch, M.T, Hergt, J.M and Handler, M.R., 1997. A simple method for the precise determination of $\geq 40$ trace elements in geological samples by ICPMS using enriched isotope internal standardisation: Chemical Geology. 134, 311-326.

McDonough, W.F., and Sun, S.-s.,1995, The composition of the Earth: Chemical Geology. 120, 223-253.

Pokhilenko N.P., Sobolev N.V., Cherny S.D., Mitukhin S.I and Yanygin Yu.T., 2000. Pyropes and Cromites from Nakyn field (Yakytia) and Snap Lake region (Canada) kimberlites: Evidences for anomalous lithosphere compositions. Reports of RAS. 372, 356-360

Pokhilenko N.P., McDonald J.A., Hall A.E., and Sobolev N.V., 2001. Abnormally thick Cambrian lithosphere of the Southeast Slave Craton: evidence from crystalline inclusions in diamonds and pyrope compositions in Snap lake kimberlites. Extended Abstracts volume of the Slave-Kaapvaal Workshop "A tale of two cratons". Merrickville, Ontario, Canada, Non- paginated.

Pokhilenko N.P., McDonald J.A., Sobolev N.V., Reutsky V.N., Hall A.E., Logvinova A.M., Reimers L.F., 2003. Crystalline inclusions and $\mathrm{C}$ isotope ratios in diamonds from the Snap Lake/King Lake kimberlite dyke system: evidence for ultradeep and enriched lithosperic mantle. This volume.

Orihashi, Y., Maeda, J., Tanaka, R., and Zeniya, R., 1998. Application test of $\mathrm{Sr}$ and $\mathrm{Nd}$ isotopic standards for seven GSJ rocks reference samples; JA-1, JB-1a, JB-2, JB-3, Jgb-1, JG-1a and JR-1: Geochemical Journal. 32, 205-211.

Rudnick R.L., Barth M., Horn I and McDonougth W.F., 2000. Rutile-bearing refractory eclogites: Missing link between continents and depleted mantle. Science. 287, 278-281.

Smith, C.B., 1983. $\mathrm{Pb}, \mathrm{Sr}$ and $\mathrm{Nd}$ isotopic evidence for 
sources of southern African Cretaceous kimberlites: Nature. 304, 51-54.

Smith, C.B., Gurney, J.J., Skinner, E.M.W., Clement, C.R., and Ebrachim, N., 1985. Geochemical character of southern African kimberlites: A new approach based on isotopic constraints: Transactions Geological Society South Africa. 88, 267-280.

A.M. Agashev. Institute of Mineralogy and Petrography SB RAS, Koptyug avenue-3, Novosibirsk, Russia. E-mail: agashev@uiggm.nsc.ru 